\title{
http://bjas.journals.ekb.eg \\ Estimation of Prolactin Level in Healthy and Respiratory Distressed Preterm Baby and Estimation of Risk factors
}

SA.Dabour, Y.M.Esmail, E.H.Assar and A.M.E.Abo-Eleinin

Pediatrics Dept., Faculty of Medicine, Benha Univ., Benha, Egypt

E-Mail:A.125@gmail.com

\begin{abstract}
Past investigations bring demonstrated the could be allowed part of prolactin in the improvement of RDS, Yet they didn't think about those maternal states which could impact the watched quality. We pointed with think about serum prolactin level Around sound preterm neonates Also preterm neonate for respiratory misery syndrome. Methods: those examine included 80 neonates (51 guys and 29 females). Those 1st one assembly (diseased): included 40 preterm babies for respiratory misery syndrome. Those second assembly (control): incorporated 40 solid preterm neonates. At baby subjected with research apgar score at 1 and 5 minutes. Serum Prolactin level might have been evaluated utilizing IRMA unit supplied Eventually Tom's perusing izotop Results: we watched helter skelter measurable noteworthy diminish from claiming serum prolactin level (ng/ml) Around preterm babies with RDS contrasted with the control aggregation for (P. Worth <0. 001). Prolactin need been distinguished Concerning illustration a could be allowed trigger for surfactant amalgamation Also hence it may bring a part over lung improvemen. Our comes about uncovered helter skelter statistically huge certain connection for serum prolactin level for gestational agdistis $\mathrm{P}$-value $<0$. $001 * *$ which demonstrate that prolactin expanded with expanding gestational period. Conclusion:. We presume starting with our consider that serum prolactin increments alongside more seasoned gestational agdistis What's more is emphatically corresponded with seriousness from claiming respiratory trouble. The more level serum prolactin level those that's only the tip of the iceberg extreme might have been the RDS condition.
\end{abstract}

\section{Introduction}

Respiratory trouble is answerable for $30-40 \%$ for nicu admissions in the neonatal period. Those clinical presentation of respiratory trouble in the infant incorporates apnea, cyanosis, grunting, inspiratory stridor, nasal flaring, poor feeding, Also tachypnea [1].

Transient tachypnea of the newborn, respiratory misery syndrome and meconium desire syndrome need aid The greater part as a relatable point reason for RDS , However Different different reasons need aid time permits [2].

Respiratory trouble happens for pretty nearly 7 percent about infants, What's more preparation may be essential to Doctors giving neonatal mind [3].

Respiratory misery syndrome (RDS) of the infant will be created Eventually Tom's perusing pulmonary surfactant insufficiency that is needed to decrease surface pressure In those air fluid interface What's more on keep summed up atelectasis of the alveolar ducts and alveoli [4].

Prolactin may be An polypeptide hormone that is synthesized for an discharged starting with specific units of the front pituitary gland, those lactotrophs. It may be also prepared Previously, other tissues including the breast, those decidua, the focal apprehensive framework and the safe framework [5].

Prolactin need a circadian about secretion, Plasma focuses about prolactin are those most astounding Throughout rest and the least Throughout those waking hours clinched alongside people [6].

Prolactin need huge numbers living activities Similarly as reproduction, body weight regulation, concealment about fertility, homeostasis, appetite, neurogenesis, glial Mobile capacity and mediates versatile reactions of the maternal cerebrum [7].

A significant number states would influencing Prolactin emission Likewise anxiety and lactation which is those best-known physiological boost influencing prolactin emission [8].

Serum prolactin level will be influenced by Numerous distressing states for example, such that respiratory trouble Furthermore seizures [9].

Prolactin assume a few part in lung surfactant improvemen Throughout pregnancy. Prolactin levels increment bit by bit starting with non-pregnant levels about 10-20 ng/mL with 200-400 ng/mL during term, Yet this Ascent is more level though those lady develops a few pregnancy related muddling. Prolactin done expanding centralization through an intricate system appears to take an interest to pulmonary development [10].

We pointed will analyze serum prolactin level Around sound preterm neonates Also preterm neonate with respiratory misery syndrome.

\section{Patient and method}

This study was carried out in neonatal intensive care unit, Pediatric Department, Benha University. The study included 80 neonates.

\subsection{Inclusion criteria}

1- Preterm babies (gestational age between 28 and 36 weeks)

2- Sex: Both sexes are involved.

3- Age: from Day one to Day 28.

4- Neonates admitted to NICU due to medical cause.

\subsection{Exclusion criteria}

1- Neonates with chromosomal abnormalities.

2- Neonates with congenital heart disease.

3 - Neonates with congenital anomalies.

4- The study group was subdivided into 2 subgroups:

Group 1 The diseased group : It included 40 preterm babies with Respiratory Distress Syndrome. 
Group $\Pi$ The control group : It included 40 preterm neonates without respiratory distress i.e. those breathing spontaneously in room air without oxygen support, with normal respiratory rate and normal work of breathing.

All baby subjected to investigate Apgar score at 1 and 5 minutes, Gestational age using Ballard score [11], Body Weight, Severity of respiratory distress according to Downes score [12], Neonatal reflexes, Complete blood count (CBC), C-reactive protein (CRP), Chest radiograph done on admission and repeated as required, Arterial blood gases (ABG) monitoring every 12 hours, Serum Prolactin level using IRMA kit supplied by izotop

We used the hPRL [125I] IRMA system which provides a direct quantitative in vitro determination of human prolactin in human serum. PRL can be assayed in the range $0-5000 \mu \mathrm{IU} / \mathrm{m}$ using $100 \mu \mathrm{I}$ serum sample.

\section{Results}

Their gestational age ranged from ( 29 weeks to 38 weeks) and their weight ranged between $(1250 \mathrm{gm}$ to $4120 \mathrm{gm})$. there was no statistically significant difference between groups according to sex.

There was highly statistically significant difference between groups according to G.A. there was highly statistically significant difference between groups according to weight. Ther was statistically significant difference between groups according to labour type. There was no statistically significant difference between groups according to maternal age (years).

There was highly statistically significant difference between groups according to prolactin level. There was no statistical significance difference between serum prolactin level and administration of Inotropes among diseased neonates.

Table (1) Comparison between groups according to prolactin level.

\begin{tabular}{|c|c|c|c|c|}
\hline Prolactin level & $\begin{array}{c}\text { Group A (Disease) } \\
(\mathrm{N}=\mathbf{4 0})\end{array}$ & $\begin{array}{c}\text { Group B (Control) } \\
(\mathrm{N}=\mathbf{4 0})\end{array}$ & t-test & p-value \\
\hline $\begin{array}{l}\text { Mean } \pm \text { SD } \\
\text { Range }\end{array}$ & $\begin{array}{c}100.74 \pm 42.33 \\
4.2-150\end{array}$ & $\begin{array}{c}131.95 \pm 31.33 \\
50-150\end{array}$ & 14.048 & $<0.001$ \\
\hline
\end{tabular}

There was highly statistically significant relation between serum prolactin level and mode of administration of $\mathrm{O} 2$ (CPAP-MV) among neonates with RD.

Table (2) Relation of serum prolactin level and mode of administration of O2 (CPAP-MV) among neonates with RD.

\begin{tabular}{cccc}
\hline & Statistical & \multicolumn{2}{c}{ O2 administration } \\
\cline { 2 - 3 } data & No & CPAP & MV \\
\hline & Mean \pm SD & 18 & 22 \\
Prolactin $(\mathbf{n g} / \mathbf{m l})$ & Range & $113.5 \pm 16.44$ & $88.6 \pm 17.72$ \\
& P-value & $37-150$ & $4.2-133$ \\
& & $<0.001^{* *}$ & \\
\hline
\end{tabular}

Positive correlation and significant between serum prolactin with G.A, ABG score birth weight, apgar at 5 minutes and Downes score.

Table (3) Correlation between serum prolactin level and other parameters, using Pearson Correlation Coefficient in group A.

\begin{tabular}{lcc}
\hline & \multicolumn{3}{c}{ Serum Prolactin } \\
\cline { 2 - 3 } & $\mathbf{r}$ & p-value \\
\hline GA (wks.) & 0.316 & $<0.001$ \\
ABG & -0.477 & 0.002 \\
Birth weight (g) & 0.599 & $<0.001$ \\
Maternal age/ year & -0.260 & 0.106 \\
Apgar at 5 minutes & 0.489 & $<0.001$ \\
Downes score & -0.688 & $<0.001$ \\
\hline
\end{tabular}

Receiver operating characteristics (ROC) curve was used to define the best cut off value of prolactin level was $<140.1$, with sensitivity of $77.5 \%$ specificity of $70 \%$ positive predictive value of $72.1 \%$, negative predictive value of $75.7 \%$ with diagnostic accuracy of $73.6 \%$. 


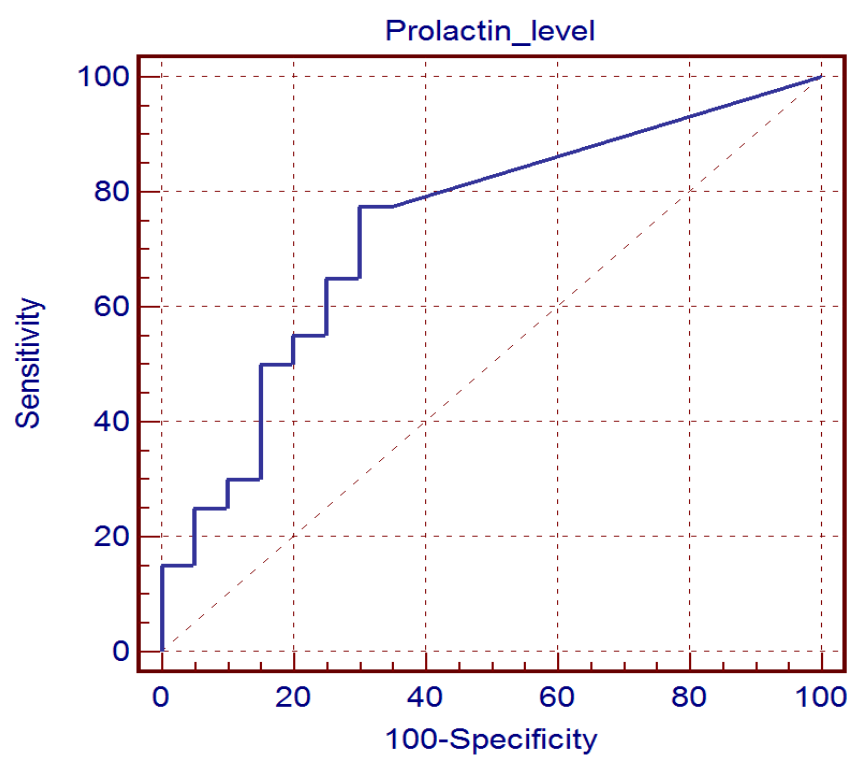

Fig (1) Receiver-operating characteristic (ROC) curve for prediction of RDS using the prolactin level.

\section{Discussion}

Past investigations bring demonstrated those conceivable part of prolactin in the advancement for RDS, Anyhow they didn't Think as of those maternal states which may impact those watched worth [10]. We meant will think about serum prolactin level "around solid preterm neonates and preterm neonate with respiratory misery syndrome. To addition, recognize if there may be At whatever relationship the middle of prolactin level and gestational age, conception weight, Apgar score, and in addition event What's more seriousness of respiratory misery syndrome. Concerning illustration see sex for our consider we accounted that male $(29(72.5 \%)$ vs $22(55 \%)$ is predominant over female (11 (27. 5\%) vs18 (45\%)) However with no statistically critical distinction between Assemblies as stated by sex. Done consent for us Kim et al. , [13], found that RDS struck them a greater amount habitually over guys (male, 53 [66. $3 \%$ ]; female, 27 [33. 7\%]; $\mathrm{p}=0.018$ ), those frequency for RDS might have been 3. 288 times higher over that On females $(\mathrm{p}=0.005)$. Comparable on $657.1 \%$ from claiming infant were male sex Also 42. $9 \%$ were female. Rijal What's more Shrestha, [14], over their contemplate discovered that $67(61.4 \%)$ neonates were male and $42(38.6 \%)$ were female for male should female proportion 1. 3:1.

Sexual orientation circulation from claiming RD cases reveals to An critical male predominance that 39 (65\%) from claiming cases were guys Also 21 (35\%) were females to a proportion about 1. 8:1 (15). As stated by Gestational period g. An (wks) to our display study, we needed intend were 34. 58 \pm 2.14 vs 36 . $93 \pm 1$. 02 with Exceedingly statistically critical distinction the middle of bunches. To favoring for us Kim et al. , [13], found that Frequencies in the gestational agdistis classifications were as takes after: 32 Previously, 37 weeks to 37 weeks 6 days, 34 for 38 on 38 weeks 6 days, 6 for 39 weeks to 39 weeks 6 days, Also 8 for In 40 weeks. Those most astounding recurrence might have been during 38 weeks $(\mathrm{p}<0$. 001) Previously, neonates for RDs. Acknowledging late-preterm births, the recurrence of RDS might have been $9.9 \%$ "around babies destined toward 34, 4. 6\% toward 35 and $1.6 \%$ during 36 weeks for gestation [16]. For examination the middle of aggregations as stated by weight $(\mathrm{kg})$ the middle of the contemplated groups, our effects that imply conception weight might

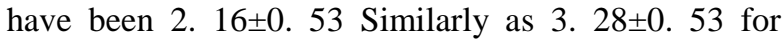
Exceptionally statistically critical Contrast the middle of bunches as stated by weight. Over understanding with us, when Ahmed et al. , [15], analyzings those conception weight about patients with RD for that of the control group, there might have been no noteworthy Contrast done their conception weight $(3.32 \pm 0.32 \mathrm{vs}$ $3.44 \pm 0.54, p=0.14)$. Other examine by Kim et al. , (13), discovered that the mean conception weight might have been 3,198 g. The recurrence of each conception weight might have been $2,000 \mathrm{~g}$ should less 2,500 g clinched alongside 3 cases, 2,500 g with less 3,000 g done 26 cases, $3,000 \mathrm{~g}$ with under $3,500 \mathrm{~g}$ to 35 cases, $3,500 \mathrm{~g}$ to under 4,000 g Previously, 12 cases, Furthermore $4,000 \mathrm{~g}$ or All the more to 4 instances done RDs gathering. In regards to mode of delivery, we found that, there were statistically noteworthy Contrast between Assemblies Similarly as 36 (90\%) from claiming our neonates conveyed by cesarean area. In the event that of the conveyance method, Kim et al. , [13], consent with us that cesarean area might have been more incessant connected with RDS over vaginal conveyance (cesarean section, 58 [72. 5\%]; vaginal delivery, 22 [27. 5\%]; $\mathrm{p}<0.001)$, those occurrence for RDS might have been 15. 034 times higher with cesarean area over for vaginal conveyance $(p<0.001)$. Contrasted with others, Mortier et al. , [17] found that neonates diagnosed for SRDS were altogether a greater 
amount often conceived Toward cesarean section: 92 $(22 \%)$ vs. $13(40 \%)$, individually $(\mathrm{p}<0.001)$ and cesarean area were $63.3 \%$, ordinary work were $35.6 \%$ What's more Ventouse work might have been $0.36 \%$. Those danger for RDS might have been higher done babies conveyed Toward elective What's more crisis cesarean section, for know ga toward birth, this news person by Condò et al. , [16]. Melamed et al. , [18]found a two-fold expanded danger from claiming RDS to babies conceived Eventually Tom's perusing cesarean section, for instances about low-risk, singlet once late-preterm conveyances.

Rijal Also Shrestha, [14], On their ponder found that $59.6 \%$ vaginally conveyed babies and $39.4 \%$ LSCS babies needed respiratory trouble.

Of the $39 \mathrm{RD}$ instances who required conveyed Eventually Tom's perusing cesarean section, the larger part $(82.5 \%)$ were conveyed electively versus main 7 cases (17. 5\%) were conveyed Toward elective cesarean area in the control assembly. Hence, elective cesarean area might have been discovered will be a danger element for RD [15]. This is in understanding with A large number other investigations for example, Badran et al. , [19], Shareef et al. , [20] What's more Tutdibi et al. , [21]. The impact from claiming laborin the individuals conveyed by typical vaginal conveyance Also crisis $\mathrm{C} / \mathrm{S}$ enhances those discharge from claiming catecholamine for maternal Also fetal circulation, bringing about $\beta$-adrenergic receptor interceded dependent upon regulation about surfactant union Also transepithelial sodium particle transport, with ensuing liquid reabsorption, in the neonatal lung. Babies conveyed through elective $\mathrm{C} / \mathrm{S}$ often are denied of this labor-related physiological stress reaction design toward conception What's more therefore background disappointment for postnatal respiratory move [21].

Done our study, there were no statistically noteworthy distinction the middle of Assemblies as stated by maternal period (years) between the

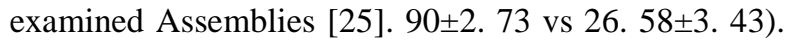
Bekdas et al. , [22]'s contemplate demonstrated no noteworthy part of maternal agdistis in the occurrence of RD. However, the part of maternal agdistis Similarly as An hazard figure for $\mathrm{RD}$ appears to be on make vague. Done addition, Kim et al. , [13], concur with us that those imply agdistis of the maternal agdistis In those conveyance might have been 34 . 0 A long time (34. 01 \pm 3 . 53). Frequencies in the maternal agdistis Classes were takes after: 7 in the 20s, 69 in the 30s, Furthermore 4 in the 40 s.

Mortier et al. , [17] accounted that, the intend maternal agdistis during conception might have been 31. 9 quite some time (SD1/45. 5; go 14-54). On particular, it might have been 31.0 A long time toward the main birth, 32. 7 a considerable length of time toward the second, 33.7 quite some time at those third and 34. 7 A long time for 4th. Clinched alongside 7. $0 \%$ from claiming births, maternal period might have been $\leq 40$ quite some time.
Qari et al. , [23], discovered that the intend period of the mother's was29. $4 \pm 6.36$ year, the intend gestational agdistis for mother's might have been 33.2 \pm 3 . 14 week and the imply equality was 2 . $48 \pm 1$. 8. On contrast, in the examine completed Eventually Tom's perusing Ahmed et al. , [15] accounted that period of the moms for RD situations hint at An noteworthy hazard variable Concerning illustration contrasted with those control gathering that $90 \%$ about instances required moms for their ages underneath 20 A long time as contradicted should best $10 \%$ in the control group, beside 77. 7\% about RD instances required An mothball agdistis over 40 quite some time contrasted with only22. $3 \%$ in the control assembly. Prolactin level between our mulled over groups, indicated that there were Exceedingly statistically noteworthy Contrast Similarly as low prolactin level may be connected with RDS (100. $74 \pm 42.33$ vs $131.95 \pm 31$. 33 ) with certain relationship and huge between serum prolactin with g. A, ABG score conception weight, apgar In 5 minutes Also Downes score.

Done favoring for us, Parvathy, [24] contemplate discovered that prolactin is essentially lower, (mean value-147. $80 \mathrm{ng} / \mathrm{ml}$ ) babies produced RDS.

The middle of 32 Furthermore 33. 5 weeks, those intend PRL focus On babies who produced RDS (101. $7 \pm 9.5 \mathrm{ng} / \mathrm{ml})$ might have been altogether lesquerella $(\mathrm{P}<0$. 025) over those PRL focus in the individuals who didn't create RDS (161. $8 \pm 18,9$ ng/ml) [25]. Over PARVATHY, [24], ponder of elevated structure group- prolactin level does expanding with expanding gestation Anyhow proportionately bring down over the Ascent for ordinary pregnancy. Ibrahim, [26], consider demonstrated that serum prolactin levels were unaesthetic Eventually Tom's perusing sex, maternal agdistis. $(p>0.05)$. We watched helter skelter Factual huge diminishing about serum prolactin level $(\mathrm{ng} / \mathrm{ml})$ "around babies for RDS contrasted with those control one assembly for (P. Esteem $\prec 0$. 001). Prolactin need been recognized Likewise a could reasonably be expected trigger to surfactant union and accordingly it might have An part done lung advancement. Padvi et al. , [10] discovered that, those mean string prolactin in the babies for RDS might have been $140 \mathrm{ng} / \mathrm{mL}$, inasmuch as in the sound baby it might have been 276 . $4 \mathrm{ng} / \mathrm{mL}$. String prolactin levels under $140 \mathrm{ng} / \mathrm{mL}$ were connected with secondary frequency from claiming respiratory misery syndrome. Same time in the study, it might have been watched that string prolactin levels less $200 \mathrm{ng} / \mathrm{mL}$ were portrayed Toward secondary frequency from claiming respiratory misery syndrome. The investigation Additionally indicated that prolactin might alternately might not specifically impact lung development $\mathrm{Be}$ that is certainly connected with gestational agdistis Anyway there may be An noteworthy relationship the middle of conception weight What's more RDS. 
Patil et al. , [27] accounted that, the imply string prolactin in the babies for RDS might have been 140 $\mathrm{ng} / \mathrm{mL}$, while in the sound newborn child it might have been $276.4 \mathrm{ng} / \mathrm{mL}$. String prolactin levels under 140 $\mathrm{ng} / \mathrm{mL}$ were connected with helter skelter frequency about respiratory misery syndrome. Previously, addition, string serum prolactin levels required no connection with the mode of conveyance. However, there were An certain connection the middle of birthweight Also prolactin. Gaikwad et al. , [28], likewise found that fetal string intend serum prolactin levels were essentially low to babies who needed respiratory trouble. Thus, babies with RDS needed an easier PRL level Likewise contrasted with babies who didn't bring RDS (271. $73 \mathrm{ng} / \mathrm{ml}$ vs $381.06 \mathrm{ng} / \mathrm{m})$. On connection of serum prolactin level What's more mode about organization of O2 (CPAP-MV) Around neonates for $\mathrm{RD}$, our effects accounted that, there were Exceptionally statistically huge connection between serum prolactin level Also mode for organization about O2 (CPAP-MV) "around neonates with RD. Padvi et al. , [10] discovered that, babies for the most reduced plasma prolactin focuses happening normally during a nadir the middle of times 5 Also 12, indicated An $120 \%$ increment in the span of ventilatory aid required. Viewing connection from claiming serum prolactin level What's more organization from claiming Inotropes Around ailing neonate, we discovered that there were no Factual essentialness distinction the middle of serum prolactin level What's more organization for Inotropes Around ailing neonates. Over concur with us, Ekmen et al. , [29] accounted that, serum PRL levels were essentially higher clinched alongside bunch 1 over in Assemblies 2 and 3 (p50. 05), However there might have been no noteworthy distinction between gatherings 2 Also 3 (p40. 05) at confirmation from claiming inotropes. This distinction disappeared toward the resulting time, Also all three Assemblies exhibited an expand for PRL levels through those course from claiming duration of the time.

\section{References}

[1] C.Dhandapani, C.Sankar,O.S.Mohan Prabhu. "A PROSPECTIVE observational study on respiratory distress and its management in neonatal intensive care unit,2017.

[2] J.Jackson, Craig. "Respiratory Disorders in the Preterm Infant." In Avery's Diseases of the Newborn (Tenth Edition), pp. 653-667,2018.

[3] McPherson, Christopher, A.Jennifer Wambach. "Prevention and Treatment of Respiratory Distress Syndrome in Preterm Neonates." Neonatal Network, Vol.37, pp. 3 169-177,2018.

[4] N.H.Hillman , H.S.Lam. Respiratory Disorders in the Newborn. In: Kendig's Disorders of the Respiratory Tract in Children. Content Repository Only, Vol.4, PP.338-366,2019.
[5] Johnson, H.Martin Essential reproduction. John Wiley \& Sons, 2018.

[6] K.Takakusaki, Y.Ohta, S.Mori. "the major criteria for the neural sleep factor that mediates these somnogenic effects of prolonged wakefulness by acting through adenosinebinding A1 and A2a receptors [133]." Oxford Textbook of Sleep Disorders, Vol.50, 2017

[7] J.r.Guillette, J.Louis. "The Neuroendocrine System and General Mechanisms of Endocrine Disruption." Endocrine Disruptors, Brain, and Behaviors, Vol.73,2017.

[8] G.Mastorakos, M.Pavlatou, E.DiamantiKandarakis. Prolactin hormone and stress. Ped. Endocrin, Vol.4(2), PP. 73-89,2005.

[9] Jacobs, S.Claire, P.Imoigele Aisiku. "Seizure Activity." Neurologic Emergencies. Springer, Cham, Vol.8, PP. 59-84,2018.

[10] Padvi, V.Namrata, R.Hemraj Narkhede. "Prolactin level in blood of newborn and its relation to respiratory distress syndrome." International J.,Reproduction, Contraception, Obstetrics and Gynecology, Vol.6 2, PP.433438,2017.

[11] J.L.Ballard, J.C.Khoury, K.Wedig. New Ballard Score, expanded to include extremely premature infants. J Pediatrics, Vol.119, PP.417-423,1991.

[12] J.J.Downes, D.W.Wood, H.I.Locks. A clinical score forthe diagnosis of respiratory failure. Amer J. Dis. 1972; Child.123.

[13] J.H.Kim, S.M.Lee, Y.H.Lee. Risk factors for respiratory distress syndrome in full-term neonates. Yeungnam University J.,Medicine, Vol.35(2), PP.187.2018,

[14] P.Rijal , M.Shrestha. Scenario of neonatal respiratory distress in tertiary hospital. Birth, Vol.14(10), PP. 6,2018.

[15] I.A.Ahmed, S.A.Hommadi, S.A.Raheem . Early respiratory distress in full term newborns. The Pharma Innovation Journal, Vol.8(2), PP.638644,2019.

[16] V.Condò, S.Cipriani, M.Colnaghi. Neonatal respiratory distress syndrome: are risk factors the same in preterm and term infants?. The J.,Maternal-Fetal \& Neonatal Medicine, Vol.30(11), PP.1267-1272,2017.

[17] I.Mortier, J.Blanc, B.Tosello. Is gestational diabetes an independent risk factor of neonatal severe respiratory distress syndrome after 34 weeks of gestation? A prospective study. Archives of Gynecology and Obstetrics, Vol.296(6), PP.1071-1077,2017.

[18] N.Melamed, G.Klinger, K.Tenenbaum-Gavish. Short-term neonatal outcome in low-risk, spontaneous, singleton, late preterm deliveries. Obstetrics \& Gynecology, Vol.114(2 Part 1), PP. 253-260,2009.

[19] E.F.Badran, M.M.Abdalgani, M.A.Al-Lawama. Effects of perinatal risk factors on common neonatal respiratory morbidities beyond 36 
weeks of gestation. Saudi Med J, Vol.33(12), PP. 1317-23,2012.

[20] A.J.Shareef, M.B.Naaom ， N.N.Hameed. Transient Tachypnea of Newborn in Neonatal Care Unit of Children Welfare Hospital Medical City/Baghdad. J.,the Faculty of Medicine, Vol.57(1), PP.6-9,2015.

[21] E.Tutdibi, K.Gries, M.Bücheler. Impact of labor on outcomes in transient tachypnea of the newborn: population-based study. Pediatrics, Vol.125(3), PP. e577-e583,2010.

[22] M.Bekdas, S.B.Goksugur, B. Kucukbayrak. The causes of prolonged transient tachypnea of the newborn: a cross-sectional study in a Turkish maternity hospital. SEEHSJ, Vol.3(2), pp.152158,2013.

[23] S.A.Qari, A.A.Alsufyani, S.H.Muathin. Prevalence of respiratory distress syndrome in neonates. The Egyptian J.,hospital medicine, Vol.70(2), PP.257-264,2018.

[24] P.Parvathy. Role of Prolactin In Fetal Lung Maturation. University J.,Surgery and Surgical Specialities, Vol.2(7), PP. 1-4,2017.
[25] B.Paturi, R.M.Ryan, K.A.Michienzi, Galactorrhea with metoclopramide use in the neonatal unit. J.,Perinatology, Vol.29(5) , PP. 391-392,2009.

[26] Z.Y.Ibrahim, Serum prolactin levels in preterm neonates with respiratory distress syndrome. Master's thesis, Cairo university,2012.

[27] B.Patil, V.Malkar, V.Karale. Foetal Cord Serum Prolactin: Levels and Association in Complications of pregnancy and Respiratory Distress Syndrome (RDS). Int J Biomed Res, Vol.7(5), PP.256-259,2016.

[28] V.Gaikwad, H.Deshpande , P.Pharande Fetal cord serum prolactin (PRL) levels in normal and abnormal pregnancies and its relation to development of RDs. Int $\mathbf{J}$ Clin Obstet Gynaecol, Vol.2(1), PP. 85-88,2018.

[29] S.Ekmen, H.Degirmencioglu, N.Uras, Effect of dopamine infusion on thyroid hormone tests and prolactin levels in very low birth weight infants. The J.,Maternal-Fetal \& Neonatal Medicine, Vol.28(8), PP.924-927,2015. 